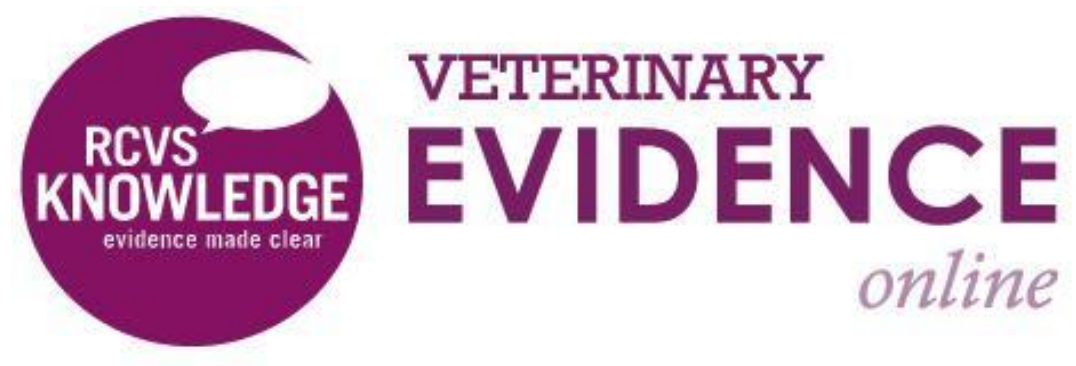

\title{
Is the Use of Hypertonic Saline Effective in Reducing Intracranial Pressure After Traumatic Brain Injury in Dogs?
}

\section{A Knowledge Summary by}

Alexandra Tischer DrVetMed, Vets Now ${ }^{1 *}$

Ava Firth DVM, DACVECC ${ }^{1}$

\footnotetext{
${ }^{1}$ Vets Now Support Office, Penguin House, Castle Riggs, Dunfermline, Fife, KY11 8SG

*Corresponding Author (a.tischer@gmail.com)
}

ISSN: 2396-9776

Published: 15 May 2017

in: Vol 2, Issue 2

DOI: http://dx.doi.org/10.18849/ve.v2i2.94

Reviewed by: Shailen Jasani (MA, VETMB, MRCVS, DACVECC) and Bruce Smith (BVSc, MS, FANZCVS, DACVS) 


\section{KNOWLEDGE SUMMARY}

\section{Clinical bottom line}

Hypertonic saline appears to be effective in reducing intracranial pressure after traumatic brain injury in dogs in experimental studies.

\section{Question}

In dogs with traumatic brain injury, does hypertonic saline, compared to lactated Ringer's solution, reduce intracranial pressure?

\section{Clinical Scenario}

A three year old $15 \mathrm{~kg}$ male entire Terrier cross is brought in after running into the road and colliding with a car. It is in hypovolaemic shock and after fluid resuscitation ( $25 \mathrm{ml} / \mathrm{kg}$ LRS in 15 minutes) the only visible injuries found are epistaxis and a fractured jaw. However, the dog is stuporous and consciousness does not seem to improve with stabilising cardiovascular parameters.

Would treatment with hypertonic saline be beneficial for this dog?

\section{The Evidence}

Nearly all available evidence for this PICO question comes from experimental studies. How much experimental and clinical traumatic brain injury differ is unclear.

\section{Summary of the evidence}

\section{Abbreviations Used}

CPP cerebral perfusion pressure

CVP central venous pressure

ICP intracranial pressure

LRS lactated Ringer's solution

MAP mean arterial pressure

\begin{tabular}{|r|l|}
\hline \multicolumn{2}{|c|}{ Prough (1986) } \\
\hline Population: & Dogs \\
\hline Sample size: & 17 \\
\hline Intervention details: & $\begin{array}{l}\text { After } 30 \text { minutes of experimentally induced haemorrhagic shock } \\
\text { (MAP }<50 \mathrm{mmHg} \text { ) dogs were resuscitated with hypertonic saline } \\
\text { solution or LRS. }\end{array}$ \\
\hline
\end{tabular}




\begin{tabular}{|c|c|}
\hline Study design: & Randomised, experimental study. \\
\hline Outcome studied: & Systolic and diastolic blood pressure, cardiac output, MAP and ICP. \\
\hline $\begin{array}{l}\text { Main findings: } \\
\text { (relevant to PICO question): }\end{array}$ & $\begin{array}{l}\text { ICP after resuscitation with hypertonic saline was lower than after } \\
\text { LRS while restoring systolic blood pressure and cardiac output to the } \\
\text { same level. }\end{array}$ \\
\hline Limitations: & $\begin{array}{l}\text { - } \text { experimental study } \\
\text { - } \text { no brain injury or increased ICP to begin with } \\
\text { - } \quad \text { small number of cases }\end{array}$ \\
\hline
\end{tabular}

\begin{tabular}{|c|c|}
\hline \\
\hline \multicolumn{2}{|r|}{ Laboratory Beagles } \\
\hline Sample size: & 22 \\
\hline Intervention details: & $\begin{array}{l}\text { Hypovolaemic shock and closed head injury were simulated via } \\
\text { bleeding of } 40 \% \text { of blood volume and epidurally inflated balloon in } \\
17 \text { dogs. This was maintained for } 1 \mathrm{~h} \text {, after that resuscitation with the } \\
\text { shed blood and either } 3 \% \text { hypertonic saline ( } 6 \text { dogs), } 0.9 \% \text { saline ( } 5 \\
\text { dogs) or dextran- } 40 \text { ( } 6 \text { dogs) was attempted. A solution of Evans } \\
\text { Blue was also injected. After } 2 \mathrm{~h} \text { of resuscitation the dogs were } \\
\text { euthanised and their brains weighed and checked for Evans Blue } \\
\text { staining under microscope. A control group of five dogs wasn't bled } \\
\text { or ballooned but normal saline and Evans Blue solution only. }\end{array}$ \\
\hline Study design: & Experimental controlled study. \\
\hline Outcome studied: & $\begin{array}{l}\text { Continuous ICP monitoring, blood brain barrier function assessed by } \\
\text { degree of Evans Blue staining and cerebral oedema formation } \\
\text { assessed by wet brain weights. }\end{array}$ \\
\hline $\begin{array}{l}\text { Main findings: } \\
\text { (relevant to PICO question): }\end{array}$ & $\begin{array}{l}3 \% \text { hypertonic saline caused lower intracranial pressure and less } \\
\text { cerebral oedema than either } 0.9 \% \text { saline or dextran- } 40 \text {, but blood } \\
\text { brain barrier integrity is not restored. }\end{array}$ \\
\hline Limitations: & $\begin{array}{l}\text { - } \quad \text { experimental study } \\
\text { - } \text { no survivors to assess clinical outcome } \\
\text { - } \quad \text { short term study of only } 3 \mathrm{~h} \text { duration } \\
\text { - } \text { smamber of cases }\end{array}$ \\
\hline
\end{tabular}

\begin{tabular}{|r|l|}
\hline \multicolumn{2}{|l|}{ Gunnar (1989) } \\
\hline Population: & Laboratory Beagles \\
\hline Sample size: & 18 \\
\hline Intervention details: & $\begin{array}{l}\text { Hypovolaemic shock and closed head injury were simulated via } \\
\text { bleeding of 40\% of blood volume and epidurally inflated balloon. } \\
\text { This was maintained for 1h, after that resuscitation with the shed } \\
\text { blood and either 3\% hypertonic saline, 0.9\% saline or dextran-40 }\end{array}$ \\
\hline
\end{tabular}




\begin{tabular}{|r|l|}
\hline & $\begin{array}{l}\text { was attempted, after this, normal saline was given at a rate to } \\
\text { maintain CVP at 10mmHg. }\end{array}$ \\
\hline Study design: & Experimental uncontrolled study. \\
\hline Outcome studied: & $\begin{array}{l}\text { Cerebral blood flow and ICP were measured at baseline, at the end } \\
\text { of the shock period, during resuscitation and after resuscitation. }\end{array}$ \\
\hline Main findings: & $\begin{array}{l}\text { Though the intracranial pressure was lower in the hypertonic saline } \\
\text { (relevant to PICO question): }\end{array}$ \\
\hline Limitations: & $\begin{array}{l}\text { - experimental study } \\
\text { - no assessment of clinical outcome } \\
\end{array}$ \\
$\begin{array}{l}\text { - short term study of only 3h duration } \\
\text { sill number of cases }\end{array}$ \\
\hline
\end{tabular}

\begin{tabular}{|c|c|}
\hline \multicolumn{2}{|l|}{ Pinto (2006) } \\
\hline Population: & Crossbreed dogs \\
\hline Sample size: & 15 \\
\hline Intervention details: & $\begin{array}{l}20 \text { minutes after experimentally induced haemorrhagic shock via } \\
\text { bleeding to MAP of } 40 \mathrm{mmHg} \text { and simulated traumatic brain injury } \\
\text { via fluid percussion and epidural balloon, volume was replaced with } \\
3 \% \text { hypertonic saline ( } 8 \mathrm{ml} / \mathrm{kg} \text { over } 10 \mathrm{~min} \text { ) or LRS ( } 16 \mathrm{ml} / \mathrm{kg} \text { over } 10 \\
\mathrm{ml} \text { ) in five dogs each. } 20 \text { minutes later shed blood and more of the } \\
\text { previous fluids were given to a haematocrit of } 30 \% \text { and a MAP of } \\
>70 \mathrm{~mm} \mathrm{Hg} \text {. A control group of five received no fluids at either point. } \\
\text { After } 60 \text { minutes the epidural balloon was deflated in the treatment } \\
\text { groups. }\end{array}$ \\
\hline Study design: & Experimental, randomised, controlled study. \\
\hline Outcome studied: & MAP, cardiac index, ICP, CPP, biochemistry and blood gases. \\
\hline $\begin{array}{l}\text { Main findings: } \\
\text { (relevant to PICO question): }\end{array}$ & $\begin{array}{l}\text { 3\% hypertonic saline results in lower ICP than LRS even though CPP } \\
\text { remains similar. Hypertonic saline also causes higher serum sodium } \\
\text { concentration and osmolarity than LRS. }\end{array}$ \\
\hline Limitations: & $\begin{array}{l}\text { - } \quad \text { experimental study } \\
\text { - no clinical outcome described } \\
\text { - } \quad \text { small number of cases }\end{array}$ \\
\hline
\end{tabular}

\begin{tabular}{|r|l|}
\hline \multicolumn{2}{|l|}{ Sharma (2015) } \\
\hline Population: & $\begin{array}{l}\text { Client-owned dogs with head trauma <5 days before hospital } \\
\text { admission. }\end{array}$ \\
\hline Sample size: & 72 \\
\hline Intervention details: & No specific interventions, clinical records were analysed. \\
\hline Study design: & Retrospective descriptive study, based on medical records. \\
\hline
\end{tabular}




\begin{tabular}{|r|l|}
\hline Outcome studied: & $\begin{array}{l}\text { The prognostic value of clinical and laboratory variables, scoring } \\
\text { systems and treatments (such as hypertonic saline) in dogs with } \\
\text { head trauma was calculated. }\end{array}$ \\
\hline (relevant to PICO question): & $\begin{array}{r}\text { Hypertonic saline administration was associated with lower } \\
\text { likelihood of survival to discharge (8 survivors, } 4 \text { nonsurvivors). }\end{array}$ \\
\hline Limitations: & $\begin{array}{r}\text { - retrospective case study } \\
\text { - no control group }\end{array}$ \\
& $\begin{array}{l}\text { - multiple parameters observed, prognostic value of individual } \\
\text { small number of cases }\end{array}$ \\
\hline
\end{tabular}

\begin{tabular}{|c|c|}
\hline \multicolumn{2}{|l|}{ Pinto (2015) } \\
\hline Population: & Crossbreed dogs \\
\hline Sample size: & 15 \\
\hline Intervention details: & $\begin{array}{l}20 \text { minutes after experimentally induced haemorrhagic shock via } \\
\text { bleeding to MAP of } 40 \mathrm{mmHg} \text { and simulated traumatic brain injury } \\
\text { via fluid percussion and epidural balloon, volume was replaced with } \\
3 \% \text { hypertonic saline ( } 8 \mathrm{ml} / \mathrm{kg} \text { over } 10 \mathrm{~min} \text { ) or LRS ( } 16 \mathrm{ml} / \mathrm{kg} \text { over } 10 \\
\mathrm{~min} \text { ) in } 5 \text { dogs each. } 20 \text { minutes later shed blood and more of the } \\
\text { previous fluids were given to a haematocrit of } 30 \% \text { and a MAP of } \\
>70 \mathrm{~mm} \mathrm{Hg.} \mathrm{A} \mathrm{control} \mathrm{group} \mathrm{of} \mathrm{five} \mathrm{dogs} \mathrm{received} \mathrm{no} \mathrm{fluids} \mathrm{at} \mathrm{either} \\
\text { point. After } 1 \mathrm{~h} \text { the epidural balloon was deflated in the treatment } \\
\text { groups. All dogs were euthanised after } 3 \mathrm{~h} \text { and the brains removed, } \\
\text { visually assessed and further analysed after tissue fixation. }\end{array}$ \\
\hline Study design: & Experimental controlled study. \\
\hline Outcome studied: & $\begin{array}{l}\text { MAP and ICP were measured, changes in pupil state were assessed } \\
\text { every } 10 \text { minutes, macroscopic and microscopic brain pathology and } \\
\text { prostaglandoid production were assessed. }\end{array}$ \\
\hline $\begin{array}{l}\text { Main findings: } \\
\text { (relevant to PICO question): }\end{array}$ & $\begin{array}{l}\text { ICP was the lowest in the hypertonic saline cases during the initial } 60 \\
\text { minutes. In brains that had received hypertonic saline, no cerebral } \\
\text { oedema was identified macroscopically and ischaemic lesions were } \\
\text { less evident. In cases with pupil changes, the pupils reversed to } \\
\text { normal sooner in the hypertonic saline group. }\end{array}$ \\
\hline Limitations: & $\begin{array}{l}\text { - } \quad \text { experimental study } \\
\text { - no survivors to assess clinical outcome } \\
\text { - } \text { short term study of only } 3 \mathrm{~h} \text { duration } \\
\text { - macroscopic assessment for cerebral oedema only } \\
\text { - } \quad \text { small number of cases }\end{array}$ \\
\hline
\end{tabular}

\section{Appraisal, application and reflection}

The purpose of this Knowledge Summary was to look at the evidence for the use of hypertonic saline in 
reducing intracranial pressure in head trauma patients.

The experimental studies available in dogs seem to indicate that hypertonic saline might have a good effect on increased intracranial pressure after traumatic brain injury while achieving desirable haemodynamic parameters.

There are no controlled clinical studies that evaluate the use of hypertonic saline as an independent variable. In the descriptive study from Sharma \& Holowaychuck (2015) the decision to use hypertonic saline was the clinician's, and sometimes made after other treatment options had been unsuccessful. The choice to use hypertonic saline appears mostly to have been made in very severe cases, which may explain the negative predictive value of hypertonic saline use on survival until discharge.

In conclusion, hypertonic saline appears to be effective in reducing intracranial pressure after traumatic brain injury in experimental studies. How effective its use might be in clinical settings cannot be answered.

\section{Methodology Section}

\begin{tabular}{|r|l|}
\hline \multicolumn{2}{|l|}{ Search Strategy } \\
\hline $\begin{array}{r}\text { Databases searched and dates } \\
\text { covered: }\end{array}$ & $\begin{array}{l}\text { PubMed database, accessed via the NCBI website (1910- } \\
\text { 2015) and the CAB abstracts database (1973-2015) }\end{array}$ \\
\hline Search terms: & $\begin{array}{l}\text { (dog OR dogs OR canine OR puppy OR puppies OR canis) } \\
\text { AND (((brain AND (trauma OR injur*)) OR (head AND } \\
\text { (trauma OR injur*)) AND (hypertonic AND (saline OR } \\
\text { sodium)) }\end{array}$ \\
\hline Dates searches performed: & $18^{\text {th }}$ July 2016 \\
\hline
\end{tabular}

\begin{tabular}{|c|c|}
\hline \multicolumn{2}{|l|}{ Exclusion / Inclusion Criteria } \\
\hline Exclusion: & $\begin{array}{l}\text { Articles not available in English or German, single case } \\
\text { reports, book chapters and conference proceedings, articles } \\
\text { which were not relevant to the question. }\end{array}$ \\
\hline Inclusion: & $\begin{array}{l}\text { Articles available in English or German, which were relevant } \\
\text { to the question. }\end{array}$ \\
\hline
\end{tabular}

\begin{tabular}{|l|c|c|c|c|}
\hline \multicolumn{1}{|c|}{ Search Outcome } & Number of results & $\begin{array}{c}\text { Excluded - } \\
\text { language }\end{array}$ & $\begin{array}{c}\text { Excluded - not } \\
\text { relevant to question }\end{array}$ & $\begin{array}{c}\text { Total relevant } \\
\text { papers }\end{array}$ \\
\hline CAB Abstracts & 2 & 0 & 1 & 1 \\
\hline PubMed & 15 & 0 & 9 & 6 \\
\hline Total relevant papers when duplicates removed & & & 6 \\
\hline
\end{tabular}




\section{CONFLICT OF INTEREST}

The author declares no conflict of interest.

\section{REFERENCES}

1. Gunnar, W. et al. (1988) Head injury and hemorrhagic shock: studies of the blood brain barrier and intracranial pressure after resuscitation with normal saline solution, $3 \%$ saline solution, and dextran40. Surgery, 103 (4), pp. 398-407.

2. Gunnar, W. Kane, J. \& Barrett, J. (1989) Cerebral blood flow following hypertonic saline resuscitation in an experimental model of hemorrhagic shock and head injury. Brazilian journal of medical and biological research = Revista brasileira de pesquisas medicas e biologicas / Sociedade Brasileira de Biofisica ... [et al.], 22 (2), pp. 287-289.

3. Pinto, F.C.G. et al. (2015) Effect of volume replacement during combined experimental hemorrhagic shock and traumatic brain injury in prostanoids, brain pathology and pupil status. Arquivos de neuropsiquiatria, 73 (6), pp. 499-505. http://dx.doi.org/10.1590/0004-282X20150039

4. Pinto, F.C.G. et al. (2006) Volume replacement with lactated Ringer's or $3 \%$ hypertonic saline solution during combined experimental hemorrhagic shock and traumatic brain injury. The Journal of trauma, 60(4), pp. 758-63- discussion 763-4. 10.1097/01.ta.0000214581.89316.73

5. Prough, D.S. JOHNSON, J.C. \& Poole, G.V.J. (1986) Effects on intracranial pressure of resuscitation from hemorrhagic shock with hypertonic saline versus lactated Ringer's solution. Journal of Trauma and Acute Care Surgery, 26 (1), p. 97.

6. Sharma, D. \& Holowaychuk, M.K. (2015) Retrospective evaluation of prognostic indicators in dogs with head trauma: 72 cases (January-March 2011). Journal of Veterinary Emergency and Critical Care, 25 (5), pp. 631-639. 10.1111/vec.12328 


\section{Cinam \\ ochese}

\section{Intellectual Property Rights}

Knowledge Summaries are a peer-reviewed article type which aims to answer a clinical question based on the best available current evidence. It does not override the responsibility

of the practitioner. Informed decisions should be made by considering such factors as individual clinical expertise and judgement along with patient's circumstances and owners' values. Knowledge Summaries are a resource to help inform and any opinions expressed within the Knowledge Summaries are the author's own and do not necessarily reflect the view of the RCVS Knowledge.

Authors of Knowledge Summaries submitted to RCVS Knowledge for publication will retain copyright in their work, but will be required to grant to RCVS Knowledge an exclusive license of the rights of copyright in the materials including but not limited to the right to publish, re-

publish, transmit, sell, distribute and otherwise use the materials in all languages and all media throughout the world, and to license or permit others to do so.

Authors will be required to complete a license for publication form, and will in return retain certain rights as detailed on the form.

Veterinary Evidence and EBVM Network are RCVS Knowledge initiatives. For more information please contact us at editor@veterinaryevidence.org

RCVS Knowledge is the independent charity associated with the Royal College of Veterinary Surgeons (RCVS). Our ambition is to become a global intermediary for evidence based veterinary knowledge by providing access to information

that is of immediate value to practicing veterinary professionals and directly contributes to evidence based clinical decision-making.

www.veterinaryevidence.org

RCVS Knowledge is a registered Charity No. 230886. Registered as a Company limited by guarantee in England and Wales No. 598443.

Registered Office:

Belgravia House

62-64 Horseferry Road

London SW1P 2AF 